\title{
Znaczenie konsultacji społecznych w formułowaniu polityki publicznej Unii Europejskiej
}

\section{Streszczenie}

W procesie formułowania polityki publicznej Unii Europejskiej istotną rolę odgrywają mechanizmy deliberatywne, które mają rekompensować niedostatek demokracji przedstawicielskiej. Jednym z nich są konsultacje społeczne prowadzone głównie przez Komisję Europejską. Artykuł zawiera analizę roli otwartych konsultacji publicznych w programowaniu i realizacji unijnej polityki sektorowej. Wyraźnie widoczny jest wzrost ich znaczenia i częstość stosowania w odniesieniu do różnych rodzajow polityki gospodarczej. Konsultacje pełnią różne funkcje, przede wszystkim służą jako instrument legitymizacji podejmowanych przez Komisję decyzji oraz jako ważne źródło informacji o opiniach i stanowiskach interesariuszy. Szczegółowo analizowany jest wypadek konsultacji społecznych dotyczących umowy transatlantyckiej TTIP ze względu na jej wage dla wszystkich Europejczyków oraz masowe protesty społeczne, które już występowały i mogą również mieć miejsce w przyszłości.

Słowa kluczowe: konsultacje społeczne, polityka publiczna, deliberacja, Komisja Europejska, interesariusze, dialog obywatelski, umowa TTIP.

\section{The importance of public consultation in the formulation of public policies of the European Union}

\begin{abstract}
Public deliberation mechanisms play an important role in the process of the EU public policy making because they are to compensate the shortage of representative democracy. One of them is social consultation carried out mainly by the European Commission. The paper consists of the analysis of open public consultation role in designing and implementing the EU sector policies. Their growing importance and frequency of use with regard to the economic policy and its kinds is clearly visible. The aims of such consultations are various. They are primarily used as an instrument of legitimacy of
\end{abstract}


decisions taken by the Commission as well as an important source of information about the stakeholders' opinions and stance. The case of social consultations concerning the transatlantic agreement TTIP is analysed here in detail due to the significance of social mass protests which used to occur and owing to the importance of the agreement for all the Europeans, they may also take place in the future.

Keywords: social consultations, public policy, deliberation, European Commission, stakeholders, civil dialogue, TTIP agreement.

\section{Deliberacja w miejsce demokracji przedstawicielskiej}

Proces formułowania polityki publicznej na poziomie Unii Europejskiej ma charakter złożony, jest wielopoziomowy i wieloetapowy. Głównymi podmiotami stanowiącymi o kierunkach i zakresie tej polityki są przede wszystkim: organy i instytucje UE, państwa członkowskie, instytucje doradcze, ale również grupy interesu reprezentujące różne środowiska, dziedziny i sektory. Decyzje są najczęściej efektem działań o charakterze współpracy, przetargu i konsensusu prowadzonych przez różnych aktorów. Prowadzenie konsultacji społecznych i włączanie obywateli w proces formułowania polityki publicznej na poziomie krajowym stanowi problem dla instytucji publicznych, głównie administracji rządowej. Na poziomie UE demokratyzacja procesu stanowienia prawa staje się prawdziwym wyzwaniem.

Immanentną cechą struktury instytucjonalnej Unii jest deficyt demokracji, który oznacza niewystarczającą legitymizację demokratyczną w pierwszym etapie procesu formułowania polityki publicznej (tzw. input legitimacy). Dotyczy on braku możliwości rozliczania z odpowiedzialności władz publicznych (accountability) ${ }^{1} \mathrm{~W}$ wyniku niedostatku mechanizmów demokracji przedstawicielskiej. Aby zniwelować deficyt demokratyczny, Unia próbuje wprowadzać mechanizmy demokracji deliberatywnej. Działania te mają stworzyć i udrożnić kanały komunikacyjne między ośrodkami władzy a społeczeństwem i włączyć jego reprezentantów w proces formułowania unijnej polityki. Jest to wyraźne nawiązanie czy wręcz próba praktycznego zastosowania koncepcji Jurgena Habermasa, zgodnie z którą remedium na utratę podstawowych funkcji przestrzeni publicznej jest zwiększenie jej wymiaru komunikacyjnego i legitymizacja decyzji podejmowanych w drodze debat i kompromisów² ${ }^{2}$.

1 T. Risse, M. Kleine, Assessing the Legitimacy of the EU's Treaty Revision Methods, "Journal of Common Market Studies" 2007, vol. 45, no. 1, s. 69-80.

2 J. Habermas, Teoria działania komunikacyjnego, t. 1, Racjonalność działania a racjonalność społeczna, tłum. A.M. Kaniowski, Wydawnictwo Naukowe PWN, Warszawa 1999. 
Uchwalono także podstawy prawne dla przybliżenia Unii społeczeństwu i wprowadzenia zasad deliberacji. Zgodnie z art. 10 i 11 TUE (tytuł II) „każdy obywatel ma prawo uczestniczyć w życiu demokratycznym Unii. Decyzje winny być podejmowane w sposób jak najbardziej otwarty i zbliżony do obywatela", a instytucje UE „umożliwiają obywatelom i stowarzyszeniom przedstawicielskim wypowiadanie się i publiczną wymianę poglądów we wszystkich dziedzinach Unii”’3.

Zastosowanie mechanizmów deliberacyjnych w procesie stanowienia prawa umożliwia optymalizację podejmowanych decyzji oraz zwiększa społeczną akceptację wprowadzanej polityki. Dzięki wykorzystaniu szerokich konsultacji społecznych unijne instytucje zdobywają pełniejszą wiedzę o problemach, potrzebach i preferencjach społecznych, co zapewnia efektywność polityki europejskiej, a także zyskują wyższą legitymizację dla swojej działalności, co wzmacnia ich pozycję w strukturze instytucjonalnej UE ${ }^{5}$. Tworzony jest nowy typ legitymizacji - technokratycznej, której celem jest połączenie wyższej sprawności zarządzania poszczególnymi obszarami unijnej polityki z poprawą legitymacji społecznej. Umożliwia ona rozwój UE bez potrzeby budowania silnych instytucji federalnych i demokratycznych, a także zmniejsza wpływy polityczne państw członkowskich ${ }^{6}$.

Dlatego organy UE utrzymują otwarty, przejrzysty i regularny dialog ze społeczeństwem obywatelskim, a Komisja Europejska prowadzi szerokie konsultacje $\mathrm{z}$ zainteresowanymi stronami.

\section{Komisja Europejska jako główny organ konsultacyjny}

Obecnie to Komisja Europejska jest organem, który tworzy najbardziej rozbudowany system konsultacji, mimo iż jest kilka innych instytucji UE powołanych do prowadzenia konsultacji ze społeczeństwem obywatelskim.

Jedną z nich jest Europejski Komitet Ekonomiczno-Społeczny, który ma reprezentować interesy społeczeństwa obywatelskiego. Komitet jest organem doradczo-konsultacyjnym, szczególnie w polityce gospodarczej i społecznej, ale jego rola

3 Traktat o Unii Europejskiej - tekst skonsolidowany uwzględniający zmiany wprowadzone Traktatem z Lizbony, Dz. U. 2004.90.864/30.

4 D.J. Bailey, Governance or the crisis of governmentality? Applying critical state theory at the European level, "Journal of European Public Policy" 2006, vol. 13, no. 1, s. 16-33.

5 S. Mazey, J. Richardson, Interest Groups and EU Policy-making: organizational logic and venue shopping, w: European Union Power and Policy-making, red. J. Richardson, 2006, s. 259.

6 T.G. Grosse, Deficyt demokratyczny w Unii Europejskiej i metody jego przezwyciężania, w: Deficyt demokratyczny w Unii Europejskiej a europejskie grupy interesu, red. U. Kurczewska, Wydawnictwa UW, Warszawa 2008, s. 90. 
w strukturze instytucjonalnej jest ograniczona. Jego wysiłki na rzecz zwiększenia uprawnień konsultacyjnych zakończyły się niepowodzeniem, głównie ze względu na przejęcie tej funkcji przez Komisję oraz wyraźny sprzeciw większości interesariuszy preferujących konsultacje z KE7 . Również Komitet Regionów został powołany do prowadzenia konsultacji w polityce regionalnej i spójności, jednak nadal jest uznawany za instytucję o funkcjach jedynie pomocniczych, której opinie są zwykle marginalizowane przez inne organy.

Funkcje prowadzenia konsultacji społecznych pełni także Parlament Europejski, który jako jedyny organ o charakterze demokratycznym ma legitymację do reprezentowania interesów europejskich obywateli. Wraz z poszerzeniem kompetencji Parlament podejmował próby otwarcia się na interesariuszy poprzez organizację przesłuchań publicznych, otwartych posiedzeń komisji parlamentarnych czy powstawanie intergrup oraz prowadzenie szerokich konsultacji społecznych, m.in. poprzez organizowanie Agory Obywatelskiej. To wskazuje na inkluzywny charakter polityki Parlamentu. Jednak praktyka pokazuje, że wiele z tych działań ma charakter fasadowy i pozorny. Idea utworzenia Agory jako otwartego forum dyskusji publicznych jest jak najbardziej zasadna, ale Agora nie odgrywa właściwie żadnej roli w procesie formułowania polityki UE. Po pierwsze, jest organizowana rzadko (raz w roku), a po drugie - postulaty i inicjatywy zgłaszane na forum przez organizacje pozarządowe nie są brane pod uwagę w procesie stanowienia unijnego prawa. Co więcej, badania pokazują, że europosłowie podczas procesu legislacyjnego sprzyjają w równym stopniu interesom społecznym, co wielkiemu biznesowi. Organizacje biznesu oraz indywidualne przedsiębiorstwa mają nie mniejszy dostęp do Parlamentu niż do Komisji. To może przeczyć założeniom demokratycznego mandatu parlamentarzystów.

Głównym organem konsultacyjnym jest zatem Komisja Europejska, która nadane jej przez traktaty ${ }^{10}$ uprawnienia i obowiązki konsultacyjne traktuje jako mandat i możliwość poszerzenia swoich kompetencji oraz pełnienia roli głównego plenipotenta w zapośredniczeniu interesów społeczeństwa obywatelskiego.

7 I. Tansaescu, The European Commission and Interest Groups. Towards a Deliberative Interpretation of Stackeholder Involvement in UE Policy-making, VUBPress, Brussels 2009, s. 46.

8 U. Kurczewska, Lobbing i grupy interesu w Unii Europejskiej. Proces konsolidacji systemu, Wydawnictwo Naukowe PWN, Warszawa 2011, s. 297.

9 P. Bouwen, The Logic of Access to the European Parliament: Business Lobbying in the Committee on Economic and Monetary Affairs, "Journal of Common Market Studies" 2004, no. 3(42), s. 456.

${ }^{10}$ Traktat z Maastricht sformułował podstawy współpracy Komisji Europejskiej i grup nacisku, podkreślił potrzebę dialogu na szczeblu europejskim między pracodawcami i pracownikami a innymi instytucjami UE oraz określił partnerską pozycję grup interesu w procesie podejmowania decyzji. Również Traktat z Lizbony uznaje ważność dialogu między obywatelami, stowarzyszeniami społeczeństwa obywatelskiego i instytucjami Unii. Artykuł 11 ust. 3 TUE określa rolę KE: „Komisja Europejska prowadzi szerokie konsultacje z zainteresowanymi stronami w celu zapewnienia spójności i przejrzystości działań Unii", a artykuł 11 ust. 1 TUE mówi o dialogu wertykalnym. 


\section{Zasady i reguły prowadzenia konsultacji społecznych}

Od lat 90. Komisja Europejska rozwija system prowadzenia konsultacji i sformalizowała dialog z organizacjami obywatelskimi przez przyjęcie ogólnych zasad i minimalnych standardów zarządzania procesem konsultacji. W Białej księdze europejskiego zarządzania publicznego ${ }^{11}$ określiła zasady uspołecznienia procesów decyzyjnych, m.in.: otwartości instytucji UE, partycypacji wszystkich zainteresowanych stron w formułowaniu i wdrażaniu polityki europejskiej, odpowiedzialności i efektywności wdrażanych obszarów polityki oraz ich spójności. Na ich podstawie sformułowała i ogłosiła w komunikacie W kierunku wzmocnionej kultury konsultacji $i$ dialog $u^{12}$ ogólne zasady i minimalne standardy konsultacji z zainteresowanymi stronami, które obowiązują do dziś.

Minimalne standardy konsultacji to: zapewnienie, by każdy z uczestników konsultacji otrzymał wszystkie niezbędne informacje dotyczące propozycji regulacji; objęcie konsultacjami wszystkich grup docelowych; prowadzenie konsultacji za pośrednictwem środków komunikacji dostosowanych do celów konsultacji i oczekiwań ich uczestników; pozostawienie wystarczającego czasu na to, by umożliwić uczestnictwo w konsultacjach; potwierdzanie otrzymania odpowiedzi; publikacja raportu opisującego wyniki konsultacji oraz sposób wykorzystania ich w trakcie dokonywania oceny skutków regulacji ${ }^{13}$.

Komisja od początku preferuje stosowanie szerokich i inkluzywnych form konsultacji, które gwarantują otwartość i pluralizm reprezentacji, zapewniają konkurencję i równowagę w agregacji i realizacji różnych kategorii interesów: ekonomicznych, społecznych czy obywatelskich. Jak przyznaje w jednym z komunikatów: „Komisja zobowiązuje się do stosowania podejścia inkluzywnego w tworzeniu i implementacji polityk publicznych UE, co oznacza prowadzenie konsultacji tak szerokich, jak to tylko możliwe"14.

${ }^{11}$ European Governance. A White Paper, European Commission, COM(2001) 428, final, s. 10.

12 Towards a reinforced culture of consultation and dialogue - General principles and minimum standards for consultation of interested parties by the Commission, European Commission, $\operatorname{COM}(2002) 704$, final, Brussels 2005.

${ }_{13}$ Towards a reinforced culture of consultation and dialogue. Proposal for general principles and minimum standards for consultation of interested parties by the Commission, COM(2002) 277, European Commission, final, Brussels, 11.12.2002 r., s. 10-12.

14 Ibidem, s. 16. 


\section{Otwarte konsultacje internetowe jako główne narzędzie komunikacji ze społeczeństwem obywatelskim w formułowaniu polityki publicznej}

W ramach dialogu obywatelskiego Komisja prowadzi konsultacje w różnych formach: komitety konsultacyjne, grupy ekspertów, otwarte wysłuchania, spotkania ad hoc, konsultacje internetowe, grupy fokusowe, seminaria itp. Wybór narzędzia zależy od tego, kto ma być konsultowany, od konkretnej dziedziny, dostępnego czasu i zasobów, etapu procesu formułowania polityki. Badania ${ }^{15}$ pokazują, że otwarte konsultacje internetowe są stosowane na początkowym etapie przygotowywania agendy (agenda setting) i planowania polityki. W następnych etapach organizowane są konferencje tematyczne i grupy eksperckie. W niektórych wypadkach tworzone są fora lub platformy tematyczne, które uzupełniają wcześniejsze konsultacje.

Obecnie podstawową i najczęściej stosowaną formą są otwarte konsultacje publiczne prowadzone przez Internet. W ciągu ostatnich pięciu lat Komisja Europejska przeprowadziła 529 tego typu konsultacji, w poprzednim okresie 504, co oznacza, że rocznie uruchamianych jest ok. 100 procedur konsultacyjnych. Jeszcze do niedawna organizowane były inne formy, np. liczne komitety konsultacyjne, grupy eksperckie, europejski panel testów biznesowych, mechanizm informacji zwrotnej, ale obecnie otwarte konsultacje internetowe są formą powszechnie stosowaną.

Tabela 1 przedstawia dane na temat ogólnej liczby przeprowadzonych w latach 2010-2014 otwartych konsultacji internetowych z podziałem na poszczególne dziedziny i dyrekcje generalne (DG). Na ich podstawie można stwierdzić, że w niektórych sektorach konsultacje tego typu organizowane są często, np. w zakresie rynku wewnętrznego (85 konsultacji), konkurencyjności (55), ochrony środowiska naturalnego (52), w mniejszym stopniu w sektorze przedsiębiorstw (45), transportu (36) oraz energii (26). Natomiast w innych dziedzinach są one prowadzone znacznie rzadziej. W dużym stopniu zależy to od aktywności legislacyjnej Komisji w danej dziedzinie - w sektorach, w których uprawniona dyrekcja generalna przygotowuje liczne projekty przyszłych regulacji, również wzrasta częstość organizowania konsultacji. Jednak nie zawsze inicjatywie legislacyjnej towarzyszą otwarte konsultacje internetowe. Niekiedy stosowane są inne narzędzia deliberacyjne.

${ }^{15}$ Ch. Quttkat, P. Kotzian, Lobbying via Consultation - Territorial and Functional Interests in the Commission's Consultaion Regime, w: Functional and Territorial Interest Representation in the EU, red. M. Knodt, Ch. Quittkat, J. Greenwood, Routledge 2012, s. 55. 
Tabela 1. Liczba prowadzonych przez Komisję Europejską otwartych konsultacji publicznych w latach 2010-2014 w poszczególnych dziedzinach

\begin{tabular}{|c|c|c|c|c|c|}
\hline $\begin{array}{l}\text { Wyodrębnione dziedziny, w których prowadzono } \\
\text { otwarte konsultacje publiczne }\end{array}$ & 2010 & 2011 & 2012 & 2013 & 2014 \\
\hline Działania w dziedzinie klimatu & - & 4 & 4 & 4 & 2 \\
\hline Badania i technologie & 4 & 5 & 6 & - & 2 \\
\hline Edukacja i sport & - & 1 & 1 & - & 1 \\
\hline Energia & 4 & 6 & 6 & 6 & 4 \\
\hline Handel & 2 & 3 & 1 & 3 & - \\
\hline Konkurencja & 7 & 9 & 14 & 14 & 11 \\
\hline Konkurencyjność i innowacje & - & 1 & - & - & - \\
\hline Konsumenci & 2 & - & - & 1 & 3 \\
\hline Kultura & - & 2 & - & - & - \\
\hline Komunikacja & - & 1 & - & - & - \\
\hline Młodzież & - & 1 & - & - & - \\
\hline Podatki & 3 & 3 & 2 & 3 & 3 \\
\hline Polityka regionalna & 1 & 1 & 1 & 1 & 2 \\
\hline Pomoc humanitarna & - & 1 & - & 1 & - \\
\hline Przedsiębiorstwa & 7 & 7 & 8 & 8 & 15 \\
\hline Rolnictwo & - & 2 & 1 & 6 & 2 \\
\hline Rozwój & 1 & 3 & 1 & - & - \\
\hline Rybołówstwo i gospodarka morska & 3 & 5 & 5 & 4 & 8 \\
\hline Rynek wewnętrzny & 24 & 24 & 13 & 13 & 11 \\
\hline Równość szans & 2 & 1 & 3 & 2 & - \\
\hline Sieci komunikacyjne, treści i technologia & - & - & 5 & 5 & 2 \\
\hline Służby celne & 1 & - & - & - & - \\
\hline Społeczeństwo informacyjne & 6 & 3 & 3 & - & - \\
\hline Sport & 1 & - & - & - & - \\
\hline Sprawiedliwość i prawa podstawowe & - & 6 & 7 & 3 & 2 \\
\hline Sprawy ogólne i instytucjonalne & 3 & - & 3 & - & 3 \\
\hline Sprawy gospodarcze i finansowe & - & 1 & - & - & 2 \\
\hline Sprawy wewnętrzne & - & 2 & 2 & 2 & 2 \\
\hline Środowisko & 11 & 12 & 8 & 15 & 6 \\
\hline Transport & 4 & 6 & 10 & 8 & 8 \\
\hline Wolność, sprawiedliwość i bezpieczeństwo & 3 & 1 & - & - & - \\
\hline Zdrowie publiczne & 7 & 8 & 8 & 3 & 2 \\
\hline Razem & 96 & 130 & 113 & 99 & 91 \\
\hline
\end{tabular}

Źródło: opracowanie własne na podstawie informacji na stronie internetowej Komisji Europejskiej Twój głos w Europie, http://ec.europa.eu/yourvoice/consultations/index_pl.htm, dostęp 13.05.2015. 
Użytecznym narzędziem do monitorowania i uczestnictwa w otwartych konsultacjach jest strona internetowa Twój głos w Europie ${ }^{16}$, która umożliwia dostęp do konsultacji, forów dyskusyjnych oraz innych narzędzi. Strona została utworzona w ramach inicjatywy Interaktywne kształtowanie polityki i zawiera informacje o możliwościach dostępu do różnych form konsultacyjnych, o konsultacjach aktualnie prowadzonych i o tych już zakończonych. Podmioty zainteresowane udziałem w konsultacjach zobowiązane są do wpisania się do rejestru służącego przejrzystości ${ }^{17}$ prowadzonego wspólnie przez Komisję Europejską i Parlament Europejski.

Rejestr został utworzony w 2008 r. w ramach Europejskiej inicjatywy na rzecz przejrzystości ${ }^{18}$, której głównym celem jest podniesienie poziomu zaufania obywateli do procesu tworzenia polityki publicznej UE, zwiększenie jego transparentności oraz udrożnienie kanałów komunikacyjnych z KE. Rejestr spełnia kilka funkcji - nie tylko zwiększa przejrzystość procesu legislacyjnego, ale też zapewnia przegląd wszystkich uczestniczących w konsultacjach interesariuszy oraz zobowiązuje ich do ponoszenia odpowiedzialności za nie i przestrzegania ustalonych przez Komisję zasad etycznych $\mathrm{w}$ procedurach konsultacyjnych ${ }^{19}$.

\section{Kto bierze udział w otwartych konsultacjach społecznych?}

O rosnącej roli konsultacji w kreowaniu unijnej polityki świadczy nie tylko wzrastająca liczba uruchamianych przez komisję procedur konsultacyjnych (ok. 100 rocznie), ale też duże zaangażowanie różnych typów interesariuszy.

Na podstawie danych z rejestru służącego przejrzystości można analizować, jakie podmioty biorą udział w konsultacjach, czyje interesy reprezentują, w jakich sprawach chcą przedstawić swoje stanowisko, jakie są ich wydatki na działania lobbingowe itp. Obecnie zarejestrowanych jest ponad 7,7 tys. interesariuszy, z czego najwięcej, bo 3,9 tys., jest organizacji biznesu, w tym stowarzyszeń branżowych, przemysłowych i zawodowych oraz zatrudnionych lobbystów. Liczne są także organizacje pozarządowe reprezentujące interesy społeczne (1,9 tys.), firmy konsultingowe, kancelarie prawne i niezależni konsultanci (923). W mniejszym stopniu w konsultacjach uczestniczą

16 http://ec.europa.eu/yourvoice/index_pl.htm, dostęp 30.06.2015.

${ }^{17} \mathrm{http} / / /$ ec.europa.eu/transparencyregister/public/homePage.do

${ }^{18}$ Komunikat Europejska inicjatywa na rzecz przejrzystości. Zasady dotyczace stosunków z przedstawicielami grup interesu (rejestr $i$ kodeks postępowania), Komisja Europejska, COM(2008) 323 wersja ostateczna, Bruksela, 27.05.2008.

${ }^{19}$ D. Chabanet, The Regulation of Interest Groups in the European Union, referat wygłoszony na konferencji Connex Thematic Conference on Accountability, European University Institute, Florence, 29-30 czerwca 2007, s. 20. 
ośrodki analityczne, instytucje naukowe i badawcze (525), organizacje reprezentujące interesy regionalne (362) oraz stowarzyszenia reprezentujące kościoły i wspólnoty religijne $(40)^{20}$.

Zainteresowanie udziałem w konsultacjach jest różne, zależy ono od specyfiki danej sprawy, poziomu zaangażowania opinii publicznej i mediów, a także mobilizacji oraz zasobów organizacyjnych interesariuszy. Okazuje się, że w niektórych sektorach gospodarczych aktywność, zainteresowanie udziałem w konsultacjach i wpływem na proces decyzyjny są bardzo wysokie, w innych branżach - bardzo niskie. I tak w sektorach wysoce sfragmentaryzowanych, zdominowanych przez dużą liczbę małych i średnich przedsiębiorstw, gdzie nie ma rywalizacji oraz linii podziałów, zainteresowanie konsultacjami jest niewielkie. I odwrotnie - w sektorach dobrze zdefiniowanych i skoncentrowanych, w których istnieje wyraźna rywalizacja między grupami interesu (np. wspólny rynek, branża energetyczna, transportowa), zainteresowanie udziałem $\mathrm{w}$ konsultacjach jest duże ${ }^{21}$.

\section{Rola otwartych konsultacji publicznych w formułowaniu unijnej polityki sektorowej}

Konsultacje pełnią wiele różnych funkcji, m.in. informacyjną, partycypacyjną, edukacyjną i prewencyjną. Dla Komisji Europejskiej mają istotne znaczenie, ponieważ dostarczają wiedzy na temat oczekiwań czy potrzeb różnych podmiotów w danej dziedzinie, zapobiegają potencjalnym nieporozumieniom i konfliktom, umożliwiają rozwiązywanie problemów na wczesnym etapie procesu politycznego, chronią przed popełnieniem błędu przy podejmowaniu ważnych dla danych społeczności decyzji, ale też zwiększają legitymizację podjętych przez KE decyzji oraz wzmacniają jej pozycję wobec innych unijnych organów. Dla interesariuszy konsultacje są ważnym kanałem komunikacji, umożliwiają przedstawienie opinii i oczekiwań, dają szansę wpływu na proces stanowienia prawa, ale są też katalizatorem aktywności i mobilizacji, stymulują tworzenie koalicji oraz sojuszy, niekiedy są wykorzystywane jako forma wyrażania protestu czy niezadowolenia.

Generalnie można wyodrębnić kilka typów konsultacji: takie, których celem jest wymiana wiedzy eksperckiej oraz informacji o stanowiskach i opiniach w danej

${ }^{20}$ Dane na podstawie informacji z rejestru służącego przejrzystości http://ec.europa.eu/transparencyregister/public/homePage.do? redir=false\&locale=pl, dostęp 30.05.2015

${ }^{21}$ A. Broscheid, D. Coen, Lobbying Activity and Fora Creation in the European Union: Empirically Exploring the Nature of the Policy Good, w: EU Lobbying: Empirical and Theoretical Studies, red. D. Coen, Routledge, New York 2007, s. 23. 
sprawie, są konsultacje, które zmierzają do zainicjowania debaty publicznej o istotnych politycznie kwestiach, ale i takie, które przeradzają się w formę wyrażania sprzeciwu czy dezaprobaty.

Jako przykład konsultacji o charakterze eksperckim można podać te prowadzone na przełomie 2014 i 2015 r. w sprawie przeglądu dyrektywy dotyczącej handlu uprawnieniami do emisji $\mathrm{CO}_{2}$ (EU ETS). Wzięło w nich udział 435 interesariuszy, przy czym zdecydowaną większość stanowili przedstawiciele biznesu (stowarzyszenia biznesu i przedsiębiorstwa) - 315, mniej licznie uczestniczyli reprezentanci małych i średnich przedsiębiorstw - 45, w niewielkim stopniu wzięły udział w tych konsultacjach organizacje reprezentujące interesy społeczne - 30 oraz instytucje rządowe i regulacyjne - 14, a także obywatele i inne podmioty - $15^{22}$. Inny przykład to konsultacje w sprawie wpływu międzynarodowych standardów sprawozdawczości finansowej (IFRS) w UE przeprowadzonych w okresie sierpień - listopad 2014 r. Ze względu na dość wąski zakres tematyczny wzięło w nich udział zaledwie 200 interesariuszy, w tym głównie organizacje biznesu i przedsiębiorstwa (z sektora finansów) - 122, przedstawiciele władz krajowych (instytucji finansowych) - 29, oraz indywidualne podmioty - $49^{23}$.

Oprócz standardowych konsultacji organizowane są też specjalne, poświęcone sprawom wyjątkowo istotnym dla rozwoju UE. Przykładem są konsultacje na temat Zielonej księgi dotyczącej europejskiej inicjatywy obywatelskiej, które odbyły się na przełomie 2009 i 2010 r. Wzięło w nich udział 329 interesariuszy, w tym 160 obywateli z różnych państw członkowskich, 133 organizacje, głównie reprezentujące interesy społeczne, oraz 36 instytucji publicznych ${ }^{24}$. Wiele ze zgłoszonych postulatów zostało uwzględnionych przez Komisję i włączonych do projektu przyszłej regulacji, m.in. minimalna liczba państw członkowskich UE, z których obywatele zgłaszający inicjatywę mają pochodzić, minimalny wiek tych obywateli, przedział czasowy zbierania pod nią podpisów itp. ${ }^{25}$.

\section{Konsultacje społeczne w sprawie TTIP jako narzędzie protestu społecznego}

Komisja Europejska w 2013 r. została upoważniona przez Radę UE do prowadzenia negocjacji umowy o transatlantyckim Partnerstwie w Dziedzinie Handlu

$22 \mathrm{http} / / /$ ec.europa.eu/clima/consultations/articles/0024_en.htm

${ }^{23} \mathrm{http} / / /$ ec.europa.eu/internal_market/consultations/2014/ifrs/index_en.htm

$24 \mathrm{http} / / /$ ec.europa.eu/dgs/secretariat_general/citizens_initiative/docs/sec_2010_370_en.pdf

25 Outcome of the public consultation on the green Paper on a European Citizen's Initiative, European Commission, COM(2010) 119 final, Brussels 31.03.2010, s. 3-5. 
i Inwestycji (TTIP). Umowa przewiduje uregulowanie stosunków handlowych między UE i USA, jeśli wejdzie w życie, to obejmie ponad 40\% światowego PKB. Umowa ma zawierać postanowienia i klauzule dotyczące ochrony inwestycji oraz rozstrzygania sporów między inwestorem a państwem (ISDS). Komisja Europejska na podstawie Traktatu z Lizbony od kilku lat prowadzi działania na rzecz zreformowania obecnego systemu ochrony inwestycji i odnośnego mechanizmu rozstrzygania sporów. Zaproponowane przez Komisję podejście różni się zasadniczo od podejścia przyjętego w już istniejących 3 tys. umów, które zawierają tradycyjne klauzule dotyczące ochrony inwestycji i rozstrzygania sporów między inwestorem a państwem. Wiele z tych umów pochodzi sprzed 50 lat. Obecnie wprowadzane są nowe postanowienia dotyczące ochrony inwestycji i rozstrzygania sporów między inwestorem a państwem w umowach o handlu z Kanadą (CETA) i Singapurem. W wypadku umowy TTIP wyzwaniem okazało się zapewnienie właściwej równowagi między ochroną inwestorów a zabezpieczeniem prawa i zdolności UE oraz państw członkowskich do regulacji w interesie publicznym (ISDS).

Negocjacje między UE a USA rozpoczęły się w lipcu 2013 r., kolejne rundy rozmów odbywają się co kilka tygodni. Podczas procesu negocjacyjnego Komisja konsultuje się z Radą UE i przekazuje sprawozdania Parlamentowi Europejskiemu. Jednak w pierwszych etapach negocjacji nie ujawniała wszystkich dokumentów oraz informacji dotyczących negocjacji, co spowodowało ostrą krytykę i protesty przedstawicieli społeczeństwa obywatelskiego. Dopiero od 2014 r. Komisja Europejska zaczęła prowadzić szeroko zakrojone konsultacje z organizacjami pozarządowymi, stowarzyszeniami przedsiębiorców, związkami zawodowymi, stowarzyszeniami ekologicznymi i konsumentów oraz innymi interesariuszami. Prowadzi także sondażowe badania opinii najbardziej zainteresowanych podmiotów, w tym małych i średnich przedsiębiorstw na temat wyzwań związanych z eksportem do USA.

Komisja od początku spodziewała się, że ISDS może się spotkać z krytyką i wywołać obawy wielu środowisk. $Z$ tego powodu zdecydowała o ogłoszeniu konsultacji publicznych dotyczących stanowiska negocjacyjnego w tej sprawie. Oczekiwała odpowiedzi z sugestiami na temat oczekiwań wobec TTIP oraz propozycji innowacyjnych rozwiązań, jakie mogą być włączone do stanowiska negocjacyjnego UE. Konsultacje internetowe przeprowadzono w okresie 27.03.2014-13.07.2014, były one otwarte dla wszystkich zainteresowanych stron.

Kwestionariusz zastosowany w konsultacjach zawierał 12 kluczowych kwestii, m.in: zakres przepisów dotyczących inwestycji, niedyskryminujące traktowanie inwestorów, zapewnienie prawa do regulowania i ochrony inwestycyjnej, sprawiedliwe i równe traktowanie, przejrzystość w ISDS. Zastosowanie ustrukturyzowanego kwestionariusza pozwoliło na uzyskanie opinii i ocen dotyczących konkretnych 
elementów umowy. Załączono także tekst referencyjny umowy oparty na projekcie porozumienia miedzy UE i Kanadą.

Konsultacje spotkały się z olbrzymim zainteresowaniem społeczeństwa. Swoje opinie przedstawiło prawie 150 tys. interesariuszy, przy czym zdecydowanie dominowały odpowiedzi indywidualnych osób (99,62\%), organizacje stanowily zaledwie 0,38\%. Wśród 569 organizacji najwięcej, bo 180 , było organizacji pozarządowych reprezentujących interesy społeczne, w tym zarówno duże europejskie ugrupowania np. European Environmental Bureau, BEUC (interesy konsumentów), Greenpeace, Friends of the Earth Europe, jak też małe krajowe stowarzyszenia. Organizacje biznesu były reprezentowane zarówno przez ugrupowania ponadsektorowe, np. Business Europe, Transatlantic Business Council, jak też przez stowarzyszenia branżowe, np. ACEA (sektor motoryzacyjny), CEFIC (przemysł chemiczny), Eurometaux (metale nieżelazne). Swoje opinie przedstawiły liczne przedsiębiorstwa, w tym korporacje transnarodowe, m.in. Total, Alstom, Chevron, Philip Morris, GDF-Suez, Daimler, Japan Tobacco, ale też małe i średnie przedsiębiorstwa z państw UE. Interesujące jest to, że w konsultacjach głos zabrało ponad 30 indywidualnych MŚP, co świadczy o nadzwyczajnej mobilizacji drobnych przedsiębiorców. Także związki zawodowe przedstawiły swoje stanowiska w sprawie TTIP, w tym europejska konfederacja ETUC oraz liczne federacje krajowe i branżowe.

Tabela 2. Typ i liczba interesariuszy biorących udział w konsultacjach TTIP

\begin{tabular}{|l|c|}
\hline \multicolumn{1}{|c|}{ Typ interesariuszy } & Liczba \\
\hline Obywatele & 148830 \\
\hline Organizacje, a w tym: & 569 \\
\hline Organizacje pozarządowe (interesy społeczne) & 180 \\
\hline Inne & 137 \\
\hline Organizacje biznesu & 66 \\
\hline Przedsiębiorstwa & 60 \\
\hline Związki zawodowe & 42 \\
\hline Organizacje pozarządowe horyzontalne & 22 \\
\hline Ośrodki doradcze (think tanks) & 21 \\
\hline Firmy konsultingowe & 15 \\
\hline Instytucje rządowe i regulacyjne & 11 \\
\hline Ośrodki akademickie & 8 \\
\hline Kancelarie prawne & 7 \\
\hline Razem & 149399 \\
\hline
\end{tabular}

Źródło: opracowanie własne na podstawie Report on the online consultation on investment protection and investor-to-state dispute settlement in the Transatlantic Trade and Investment Partnership Agreement, http:// europa.eu/rapid/press-release_MEMO-15-3202_en.htm, dostęp 30.05.2015. 
Najwięcej odpowiedzi otrzymano z Wielkiej Brytanii (34\%), Austrii (22\%), Niemiec (21\%), w mniejszym stopniu z Francji (6\%), Belgii (6\%), Holandii (3\%). Z nowych państw członkowskich udział w konsultacjach był znikomy i sięgał $0,1-0,9 \%{ }^{26}$.

Podczas konsultacji przedstawiono wiele opinii i stanowisk dość krytycznie odnoszących się do zaproponowanego przez KE podejścia w negocjacjach. Najwięcej kontrowersji dotyczyło kwestii ochrony prawa do regulacji, ustanowienia i funkcjonowania sądów arbitrażowych, związku między krajowymi systemami sądowymi a ISDS oraz weryfikacji decyzji wydanych w ramach ISDS za pomocą mechanizmu odwoławczego ${ }^{27}$.

Szczególnie organizacje pozarządowe, reprezentujące interesy społeczne, wykazały się olbrzymią aktywnością i zmobilizowały tysiące członków do uczestnictwa w konsultacjach. Przygotowały i udostępniły dla wszystkich chętnych platformy internetowe oraz specjalne oprogramowanie ułatwiające wysłanie swojej opinii. Niektóre z nich zawierały wstępnie przygotowane odpowiedzi i format, który umożliwiał wysłanie licznych ankiet w krótkim czasie. Większość odpowiedzi, ok. 145 tys. (97\%), nadesłano za pośrednictwem różnych platform internetowych.

W zbiorze wszystkich nadesłanych opinii i komentarzy można zauważyć pewne prawidłowości ${ }^{28}$. Ponad połowa odpowiedzi (70 tys.) została nadesłana przez członków ośmiu organizacji pozarządowych. Można je podzielić na siedem serii zawierających niemal identyczne opinie. Kolejne 50 tys. odpowiedzi pochodzi od członków jednej organizacji i zawiera niemal taką samą odpowiedź ostro krytykującą ISDS. Pozostałe 28 tys. to opinie bardziej zróżnicowane.

Wśród wszystkich nadesłanych opinii dominowały głosy krytyczne wobec TTIP, szczególny sprzeciw wzbudziła propozycja dotycząca rozstrzygania sporów między inwestorem a państwem (ISDS). Generalnie można wyodrębnić trzy kategorie odpowiedzi:

- zawierające ogólny sprzeciw wobec TTIP,

- wyrażające obawy o ochronę inwestycji i rozstrzygania sporów między inwestorem a państwem w TTIP,

- przedstawiające konkretne uwagi na temat zaproponowanego przez KE podejścia w związku z TTIP 29 .

${ }^{26}$ Report on the online consultation on investment protection and investor-to-state dispute settlement in the Transatlantic Trade and Investment Partnership Agreement http://europa.eu/rapid/press-release_MEMO-15-3202_en.htm, dostęp 30.05.2015.

27 Sprawozdanie: Internetowe konsultacje publiczne w sprawie ochrony inwestycji i rozstrzygania sporów miedzy inwestorem a państwem (ISDS) w umowie o transatlantyckim partnerstwie handlowo-inwestycyjnym (TTIP), Komisja Europejska, SWD(2015) 3 final, Bruksela, 13.01.2015, s. 4.

${ }^{28}$ Ibidem, s. 10.

${ }^{29}$ Ibidem, s. 28. 
Pierwsza grupa opinii wyraźnie wskazuje na obawy obywateli dotyczące porozumienia TTIP jako takiego oraz co do regulacji dotyczących ochrony inwestycji i rozstrzygania sporów między inwestorami a państwem (ISDS). Obawy dotyczące ISDS zgłaszały przede wszystkim organizacje pozarządowe czy inne stowarzyszenia, w tym konsumenckie i ekologiczne oraz związki zawodowe. W ich ocenie TTIP w obecnej wersji umożliwia pozywanie rządów przez korporacje na wysokie kwoty ${ }^{30}$ oraz uprzywilejowuje duże przedsiębiorstwa i inwestorów w relacjach z państwem, a także klientami. Wielu respondentów domaga się zwiększenia ochrony dla inwestycji oraz zabezpieczenia prawa do regulacji w interesie publicznym. Powszechne jest żądanie zwiększenia przejrzystości negocjacji w sprawie ISDS.

Odmienne stanowisko zajmują przedstawiciele pracodawców i dużych przedsiębiorstw, według których inwestycje powinny podlegać szczególnej ochronie, a TTIP przyczyni się w znacznym stopniu do zwiększenia wymiany handlowej inwestycji - tym samym do wzrostu gospodarczego i społecznego w Europie, a także w USA. Bardziej sceptyczne uwagi przesłali reprezentanci małych i średnich przedsiębiorstw, którzy domagali się dla siebie większej ochrony, obawiając się nierównego traktowania partnerów w USA i w UE. Co więcej, podkreślali, że ISDS będzie korzystny głównie dla dużych korporacji, natomiast mniejsze przedsiębiorstwa nie będą $\mathrm{w}$ stanie $\mathrm{z}$ niego korzystać ze względu na wysokie koszty.

Po zapoznaniu się ze wszystkimi opiniami zgłoszonymi podczas konsultacji Komisja uznała, że należy kontynuować debatę na temat dalszych prac dotyczących TTIP, ze szczególnym uwzględnieniem czterech najbardziej krytykowanych kwestii: ochrony prawa do regulacji, ustanowienia i funkcjonowania sądów arbitrażowych, związku między krajowymi systemami sądowymi a ISDS oraz weryfikacji orzeczeń wydanych w ISDS za pomocą mechanizmu odwoławczego.

Wyniki konsultacji społecznych opublikowano w specjalnym sprawozdaniu w styczniu 2015 r. Przedstawione w nim opinie posłużyły jako podstawa do przygotowania zmodyfikowanego stanowiska KE w sprawie negocjacji z USA, w tym zagwarantowania, że specjalne procedury rozstrzygania sporów między inwestorem a państwem nie będą ograniczać jurysdykcji państw członkowskich UE. Jednak nie była to wersja ostateczna stanowiska negocjacyjnego, gdyż KE prowadziła dodatkowe konsultacje w tej sprawie z Parlamentem Europejskim oraz z ministrami ds. handlu państw UE.

Olbrzymia mobilizacja społeczna podczas konsultacji i protesty wobec propozycji KE dotyczących inwestycji w ramach TTIP spowodowały zawieszenie na kilka miesięcy negocjacji między UE i USA. Dopiero w kwietniu 2015 r. przeprowadzono

30 Ibidem, s. 15. 
dziewiątą rundę negocjacji dotyczącą dostępu do rynku oraz zasad współpracy regulacyjnej, głównie w branży energetycznej i surowców.

Jeszcze podczas trwania otwartych konsultacji internetowych KE organizacje pozarządowe i związki zawodowe podjęły dodatkowe działania w ramach protestu przeciw umowie TTIP - 5 lipca 2014 r. został złożony wniosek do Komisji Europejskiej o rejestrację 47. europejskiej inicjatywy obywatelskiej STOP TTIP, podpisany przez 148 organizacji z 18 państw i ponad milion obywateli z UE ${ }^{31}$. Koalicja STOP TTIP apelowała do Komisji Europejskiej, aby ta zarekomendowała Radzie UE wycofanie mandatu negocjacyjnego w sprawie TTIP i nie przyjęła umowy CETA. Organizacje pozarządowe zarzucały brak jawności i przejrzystości w prowadzeniu negocjacji z USA oraz argumentowały, że umowa TTIP uwzględnia głównie interesy wielkich korporacji oraz wzmacnia ich pozycję w sporach inwestor-państwo, obniża standardy ochrony konsumentów w UE i wprowadza niedemokratyczne procedury rozstrzygania sporów $\mathrm{z}$ inwestorem ${ }^{32}$.

Jednak we wrześniu 2014 r. Komisja Europejska odrzuciła wniosek o rejestrację tej inicjatywy, argumentując, że nie spełnia on wymogów formalnych - mandat negocjacyjny nie jest aktem prawnym UE, więc nie może być objęty inicjatywą obywatelską. Według KE nie można sformułować negatywnych propozycji w sprawie ratyfikacji umów i dlatego Komisja nie może zaprzestać negocjacji TTIP i CETA.

W tym wypadku otwarte konsultacje społeczne zostały wykorzystane przez organizacje pozarządowe i związki zawodowe jako możliwość zamanifestowania sprzeciwu zarówno wobec postanowień umowy, jak też wobec utajnienia i braku przejrzystości prowadzonych przez KE negocjacji. Olbrzymia oddolna mobilizacja społeczna, zgłoszenie prawie 140 tys. krytycznych opinii oraz działania dodatkowe (m.in. zgłoszenie inicjatywy obywatelskiej, nagłośnienie sprawy w mediach), a także liczne manifestacje w całej UE zmusiły Komisję Europejską do zmiany nie tylko stanowiska negocjacyjnego w sprawie umowy TTIP, ale też trybu postępowania i form komunikacji z zainteresowanymi środowiskami. Dotychczas utajniane dokumenty dotyczące negocjacji w dużej części zostały udostępnione na specjalnej stronie internetowej ${ }^{33}$, zawierającej także wszelkie informacje o postępach w pracach przygotowawczych, stosowanych procedurach, osobach odpowiedzialnych za prowadzenie negocjacji, ekspertach i ich opiniach, interesariuszach itp.

${ }^{31}$ Europejska inicjatywa obywatelska to instrument demokratyczny umożliwiający milionowi obywateli z co najmniej jednej czwartej państw członkowskich UE zwrócenie się do Komisji Europejskiej o przedłożenie propozycji aktów legislacyjnych w obszarach należących do kompetencji Komisji.

${ }_{32}$ M. Majkowska, TTIP w pigułce. Kilka faktów na temat umowy o wolnym handlu między Uniq Europejska a Stanami Zjednoczonymi, Instytut Spraw Publicznych, Warszawa 2015, s. 10.

$33 \mathrm{http} / / /$ ec.europa.eu/trade/policy/in-focus/ttip/about-ttip/questions-and-answers/index_pl.htm 
Zmienił się także styl argumentacji Komisji. Wcześniej w komunikatach przedstawiano porozumienie TTIP jako wielką zdobycz, a obawy redukowano do rangi nieuzasadnionych niepokojów osób niezorientowanych w temacie. Po konsultacjach Komisja przyznała, że jest konflikt w sprawie TTIP, są różne punkty widzenia, a niektóre krytyczne opinie zawierają konstruktywne propozycje.

Konsultacje pozwoliły nie tylko ujawnić i przedstawić różne, często sprzeczne, stanowiska, zaktywizowały wiele środowisk społecznych i pojedynczych obywateli, ale też spowodowały wprowadzenie bardziej demokratycznych procedur w pracach Komisji Europejskiej. Można zatem uznać, że stosowanie deliberatywnych narzędzi w procesie formułowania polityki publicznej zwiększa jej demokratyczną legitymizację, podnosi zaufanie obywateli i sprawia, że jest ona w większym stopniu akceptowana społecznie, a tym samym jej efektywność może być większa.

\section{$* * *$}

Proces formułowania unijnej polityki publicznej jest złożony i wielopoziomowy, uczestniczą w nim zarówno instytucje UE, państwa członkowskie, jak też interesariusze oraz inne podmioty. W sytuacji niedostatku mechanizmów demokracji przedstawicielskiej wprowadzane są procedury deliberacji. Generalnie Unia zmieniła w ciągu ostatniej dekady kierunek rozwoju i podąża w stronę zwiększenia wymiaru komunikacyjnego oraz budowania relacji ze społeczeństwem obywatelskim, oczekując, że organizacje pozarządowe będą pełniły funkcję interlokutora. Komisja Europejska próbuje stworzyć europejską przestrzeń komunikacji poprzez biurokratyczne procedury i włączanie interesariuszy do deliberacji, chociaż często są one nazbyt techniczne i wymagające eksperckiej wiedzy. Głównym narzędziem deliberacji są otwarte konsultacje społeczne, które stały się regularnie stosowanym instrumentem zasięgania opinii. Konsultacje są wysoce sformalizowane i prowadzone z zachowaniem standardów przejrzystości, otwartości i inkluzyjności. Można zatem uznać, że jest to system zinstytucjonalizowany i powszechnie stosowany. Świadczy o tym nie tylko liczba organizowanych corocznie procedur konsultacyjnych, ale też olbrzymie zainteresowanie różnych podmiotów udziałem w nich. Jednak należy pamiętać, że konsultacje służą Komisji przede wszystkim jako instrument uprawomocnienia jej decyzji i strategii oraz wzmocnienia politycznej pozycji i prestiżu w strukturze instytucjonalnej UE. Analizowany przypadek dotyczący umowy transatlantyckiej TTIP pokazuje, że konsultacje mogą być dysfunkcjonalne i obrócić się przeciw polityce Komisji. 


\section{Bibliografia}

Bailey D.J., Governance or the crisis of governmentality? Applying critical state theory at the European level, "Journal of European Public Policy" 2006, vol. 13, no. 1.

Bouwen P., The Logic of Access to the European Parliament: Business Lobbying in the Committee on Economic and Monetary Affairs, "Journal of Common Market Studies" 2004, no. 3(42).

Broscheid A., Coen D., Lobbying Activity and Fora Creation in the European Union: Empirically Exploring the Nature of the Policy Good, w: EU Lobbying: Empirical and Theoretical Studies, red. D. Coen, Routledge, New York 2007.

Chabanet D., The Regulation of Interest Groups in the European Union, referat wygłoszony na konferencji Connex Thematic Conference on Accountability, European University Institute, Florence, 29-30.06.2007.

European Governance. A White Paper, European Commission, $\operatorname{COM}(2001)$ 428, final.

Grosse T.G., Deficyt demokratyczny w Unii Europejskiej i metody jego przezwyciężania, w: Deficyt demokratyczny w Unii Europejskiej a europejskie grupy interesu, red. U. Kurczewska, Wydawnictwa UW, Warszawa 2008.

Habermas J., Teoria działania komunikacyjnego, t. 1 Racjonalność działania a racjonalność społeczna, tłum. A.M. Kaniowski, Wydawnictwo Naukowe PWN, Warszawa 1999.

http://ec.europa.eu/clima/consultations/articles/0024_en.htm

http://ec.europa.eu/dgs/secretariat_general/citizens_initiative/docs/sec_2010_370_en.pdf

http://ec.europa.eu/internal_market/consultations/2014/ifrs/index_en.htm

http://ec.europa.eu/trade/policy/in-focus/ttip/about-ttip/questions-and-answers/index_pl.htm http://ec.europa.eu/transparencyregister/public/homePage.do

http://ec.europa.eu/transparencyregister/public/homePage.do?redir=false\&locale=pl http:// ec.europa.eu/yourvoice/index_pl.htm dostęp 30.06.2015

Komunikat: Europejska inicjatywa na rzecz przejrzystości. Zasady dotyczące stosunków z przedstawicielami grup interesu (rejestr i kodeks postępowania), Komisja Europejska, $\operatorname{COM(2008)~323,~}$ wersja ostateczna, Bruksela, 27.05.2008.

Kurczewska U., Lobbing i grupy interesu w Unii Europejskiej. Proces konsolidacji systemu, Wydawnictwo Naukowe PWN, Warszawa 2011.

Majkowska M., TTIP w pigułce. Kilka faktów na temat umowy o wolnym handlu między Unia Europejska a Stanami Zjednoczonymi, Instytut Spraw Publicznych, Warszawa 2015.

Mazey S., Richardson J., Interest Groups and EU Policy-making: organizational logic and venue shopping, w: European Union Power and Policy-making, red. J. Richardson, 2006.

Outcome of the public consultation on the green Paper on a European Citizen's Initiative, European Commission, COM(2010) 119 final, Brussels 31.03.2010.

Quttkat Ch., Kotzian P., Lobbying via Consultation - Territorial and Functional Interests in the Commission's Consultaion Regime, w: Functional and Territorial Interest Representation in the EU, red. M. Knodt, Ch. Quittkat, J. Greenwood, Routledge 2012. 
Report on the online consultation on investment protection and investor-to-state dispute settlement in the Transatlantic Trade and Investment Partnership Agreement, http://europa. eu/rapid/press-release_MEMO-15-3202_en.htm, dostęp 30.05.2015.

Risse T., Kleine M., Assessing the Legitimacy of the EU's Treaty Revision Methods, "Journal of Common Market Studies" 2007, vol. 45.

Sprawozdanie: Internetowe konsultacje publiczne $w$ sprawie ochrony inwestycji i rozstrzygania sporów miedzy inwestorem a państwem (ISDS) w umowie o transatlantyckim partnerstwie handlowo-inwestycyjnym (TTIP), Komisja Europejska, $\operatorname{SWD(2015)~3,~wersja~ostateczna,~}$ Bruksela, 13.01.2015.

Tansaescu I., The European Commission and Interest Groups. Towards a Deliberative Interpretation of Stackeholder Involvement in UE Policy-making, VUBPress, Brussels 2009.

Towards a reinforced culture of consultation and dialogue - General principles and minimum standards for consultation of interested parties by the Commission, European Commission, $\operatorname{COM}(202)$ 704, final, Brussels 2005.

Traktat o Unii Europejskiej - tekst skonsolidowany uwzględniający zmiany wprowadzone Traktatem z Lizbony, Dz. U. 2004.90.864/30. 